\title{
Students' Problem in Using English E-Learning in SMP Katolik 1 WR.Soepratman Samarinda
}

\author{
Erza Praditha ${ }^{1}$, \\ ${ }^{1)}$ Program Studi Pendidikan Bahasa Inggris, Fakultas Keguruan dan Ilmu Pendidikan \\ Universitas Widya Gama Mahakam, Indonesia \\ Jl. KH. Wahid Hasyim No. 28 RT.007 Kota Samarinda, Provinsi Kalimantan Timur \\ Dedi Rahman Nur ${ }^{2}$ \\ 2) Program Studi Pendidikan Bahasa Inggris, Fakultas Keguruan dan Ilmu Pendidikan \\ Universitas Widya Gama Mahakam, Indonesia \\ Jl. KH. Wahid Hasyim No. 28 RT.007 Kota Samarinda, Provinsi Kalimantan Timur \\ echapradithaep@gmail.com ${ }^{1}$,d.blues84@gmail.com²
}

\begin{abstract}
This study intended to find out problems encountered by students when learning English through e-learning. This research is to find out what problems faced by students when learning English through E-Learning which are identified through a questionnaire distributed via Google forms to the students. The sample of this research was 86 students of the third-grade students of SMP Katolik 1 WR. In this study, the researcher computed the data used frequency distribution analysis to determine the percentage of the tendency of students problems in internal or external factors when using e-learning in English learning.

Both in terms of internal and external factor, each part are interrelated. Problem that happened with the teachers, then to the students and eventually impact the learning system which makes ineffectiveness e-learning in the school, they are affecting each other and create a domino effect.
\end{abstract}

Keywords: Problem, English Learning, E-Learning.

\section{Introduction}

Nowadays, electronic is very common everywhere and everyday technology has developed rapidly and increase sophisticatedly. In today's education, electronics media is one of the facility to assist teaching and learning activities in school. E-learning provides a new way of how to learn and find information and knowledge independently. In accordance with [4] Elearning or commonly referred to as learning based on electronic use is able to rapidly change educational scenarios. [9] said that the integration of technology in EFL is currently being accepted and developed rapidly becoming a significant aspect that can influence the success of learning and teaching. An educator in the modern era is required to think creatively and innovatively to create learning that is fun and easy to accept by students, and they will be more interested so teachers usually use electronics as a learning media.

However, learning English through E-Learning is not always be able to provide benefits, there are still many students who have problems when using electronic technology in the classroom. Often, teacher only thinks about how effective the teaching methods are without any desire to find out if there are other causes that become problems for students when learning English through E-Learning. The problem occurs because of the obstacles when students receive lessons and if the problems are not resolved it will ultimately lead to ineffectiveness learning.

Based on those considerations, the writer wants to analyze deeply on how important the problem of students in learning English through E-learning and what are the most decisive indicators of the problems experienced by students in English learning through e-learning in SMP Katolik 1 WR. Soepratman Samarinda. Based on grand theory from [1] they define elearning as a concept, a part from technology include learning strategies, Learning methods and lately it is very much directed to the vast possibilities of content diffusion and connection. Related to problem and difficulties, the writer refers to [11] opinion about the internal and external factor that causing problem. 
This research attempt to find out and answer, what problems are faced by students when learning English through E-learning in SMP Katolik 1 WR. Soepratman Samarinda.

\section{Methodology}

The design used descriptive quantitative research. According to [2] Descriptive means analyzing the meaning between qualitative and quantitative method (i.e. using numerical information or without using numerical information) to summarize and process the information obtained. Quantitative descriptive is a simple statistic that connects sample descriptions with population descriptions and its uses simple statistical computation on mean score, variation of precentages and simple mathematical account. This research used descriptive quantitative design in order to be able to describe the nature of existing conditions and the reality in the field and to accumulate specific information about a particular topic and obtained from a particular population.

Population of this research was the third-grade students of SMP Katolik 1 WR. Soepratman Samarinda that has 114 students. According to [5] simple random sampling is a process in selecting samples in which all individuals in the selected population have equal and independent opportunities for a sample selection. This study used simple random sampling and with known populations, the researcher took samples from the population used the KrejcieMorgan Table with 95\% level of confidence, the sample for this study used 86 students.

Questionnaires distributed to students through web-based questionnaires by using google forms and distributed through social media. The questionnaire used close-ended question and students are given 2 choices to answer questions and consisted of 19 questions to find out percentages about problems faced by students when learning English through e-learning. The researcher used dichotomous questionnaire Yes/No answer, this questionnaire used validity judgment by expert and this questionnaire was tryout first to 10 students of third grade SMP Katolik $1 \mathrm{WR}$ Soepratman Samarinda with questions on Google forms are not required to be answered, so students can choose to answer the questions or not, to find out the validity of the contents. The researcher shared questions (Google forms) to students via DM on Instagram. 10 students who took part in the tryout answered online questions (Google forms) from the 18th until 20th of August 2019. Each student answered each question without skipped from number 1 until number 19, it means that the questions distributed were valid and students understood what was asked in the questionnaire. For the final questionnaire test was given to 86 students of third-grade SMP Katolik WR Soepratman Samarinda on the 22nd until 23rd of August 2019. The researcher came to class and directly shared the questionnaire through social media to one student and one student shared to other students. On Thursday, August 22nd 2019, the researcher distributed questionnaires to class IX-C students from 08:45 a.m and IX-A from 11:10 a.m, students were instructed to do questionnaires for 15 minutes. On Friday, August 23rd 2019, the researcher distributed questionnaires to class IX-B students from 8:05 a.m and were asked to finish in 15 minutes. After all the data has been collected, the researcher tabulates the data. This instrument was adapted from Gilakjani (2015), Haron \& Zaid (2015), Trasierra (2018) and Mohammed (2015).

In addition, this questionnaire has indicators taken from [8] which have theories about analyzing factors that cause difficulties in English learning. Some of the difficulties are divided into two factors, that are internal and external factors, will be explained as follows: 
BORJU:Borneo Educational Journal

ISSN 2655-9323 (online)

Table 1. Indicator of Problem

\begin{tabular}{lcc}
\hline Variabel & Indicators & Item Numbers \\
\hline Internal Factor & $\begin{array}{l}\text { 1. Self Confidence } \\
\text { a) }\end{array}$ & $1,2,3$ \\
& $\begin{array}{l}\text { 2. Motivation believe in own abilities } \\
\text { a) Inner encouragement }\end{array}$ & 5 \\
\hline 3. Attitude & \\
\hline a) Students' willingness to learn & 4,6 \\
\hline External Factor & Self Esteem & \\
& a) Experience & $7,8,9$ \\
b) Feeling inferior and discouraged & \\
\hline 1. Teaching Media & $10,11,12,13,14$ \\
a) Electronic device & \\
b) Internet & \\
c) E-book & 15,16 \\
\hline 2. Classroom Condition & $17,18,19$ \\
a) Time management & \\
\hline 3. Teacher & a) Teacher experience \\
b) Teacher attitude & 19
\end{tabular}

The purpose of this study was to determine the percentage of the tendency of students problems in internal or external factors in using e-learning in English learning. The researcher used Frequency distribution analysis for data analysis techniques from [3], researchers calculated and analyzed data from questionnaires to find out what percentage of problems faced by students when learning English through e-learning

\section{Findings and Discussion}

\section{Findings}

The findings of this study are to find out the problems that students encountered when learning English through e-learning. In this study there are 86 subjects participanted from the third grade of SMP Katolik 1 WR Soepratman Samarinda.

\section{a. Result of Questionnaire}

The questionnaire is used to find out what are the problems encountered by students when learning English through E-learning. The questionnaire was distributed to the third grade of SMP Katolik 1 WR Soepratman Samarinda through Google forms. This questionnaire has 19 items and distributed to 86 students, they are from class IX-A, IX-B, and IX-C. The following table described briefly the percentage obtained for each questionnaire item:

Table 2. Problems from Internal Factor

\begin{tabular}{llcc}
\hline \multirow{2}{*}{ NO } & \multicolumn{1}{c}{ Item Questionnaire } & Yes & Frequency(\%) \\
& & $57 \%$ & No \\
\multirow{2}{*}{1} & Do you have enough experience using a & $(49)$ & $43 \%$ \\
& computer? & $84,9 \%$ & $(37)$ \\
\hline \multirow{2}{*}{2} & Are you skilled / proficient in using the & $(73)$ & $15,1 \%$ \\
& Internet? & $51,2 \%$ & $(13)$ \\
\hline \multirow{2}{*}{3} & Do you understand English well when & $(44)$ & $48,8 \%$ \\
& learning through E-Learning? & $12,8 \%$ & $(42)$ \\
\multirow{2}{*}{4} & Do you feel forced to use E-Learning because & $(11)$ & $87,2 \%$ \\
& it is required by the teacher? & $82,6 \%$ & $(75)$ \\
\hline \multirow{2}{*}{5} & Are you motivated to improve your English & $(71)$ & $17,4 \%$ \\
& skills when learning used E-Learning? & $87,2 \%$ & $(15)$ \\
\hline \multirow{2}{*}{6} & Are you interested in learning English using & $(75)$ & $12,8 \%$ \\
& E-Learning? & & $(11)$ \\
\hline
\end{tabular}




\begin{tabular}{|c|c|c|c|}
\hline \multirow{2}{*}{ NO } & \multirow{2}{*}{ Item Questionnaire } & \multicolumn{2}{|c|}{ Frequency $(\%)$} \\
\hline & & Yes & No \\
\hline 7 & $\begin{array}{l}\text { Have you been given training on how to use } \\
\text { electronics before learning English through E- } \\
\text { learning? }\end{array}$ & $\begin{array}{l}34,9 \% \\
(30)\end{array}$ & $\begin{array}{l}65,1 \% \\
(56)\end{array}$ \\
\hline 8 & $\begin{array}{l}\text { Do you know how to learn English using E- } \\
\text { Learning? }\end{array}$ & $\begin{array}{c}37,2 \% \\
(32)\end{array}$ & $\begin{array}{c}62,8 \% \\
(54)\end{array}$ \\
\hline 9 & $\begin{array}{l}\text { Are you having trouble understanding } \\
\text { information in English learning provided } \\
\text { through E-learning? }\end{array}$ & $\begin{array}{l}40,7 \% \\
(35)\end{array}$ & $\begin{array}{l}59,3 \% \\
(51)\end{array}$ \\
\hline
\end{tabular}

The results show that internal factor has several problems, which is found in number 7 and number 8 . At this point, the researcher will describe all of the items contained in internal factor, as follows:

Question number 1 "Do you have enough experience using a computer?" On this question refers to the general used of computer. It shows that $57 \%$ of students have sufficient experience in using computers, while $43 \%$ of students do not have enough experience in using computers. This question relate to the indicator of self-confidence, the researcher did not find any problems because more than half of the students had enough experience in using computers.

Question number 2 "Are you skilled/proficient in using the Internet?" On this question refers to the general used of internet. It shows that $84.9 \%$ of students believed that they were proficient in using the internet, while $15.1 \%$ of students were not confident, that they could use the internet proficiently. This question relates to the indicator of self-confidence and the researcher did not find any problems in this item.

Question number 3 "Do you understand English well when learning through E-Learning?". It shows that $51.2 \%$ of students were confident that they understand English well when learning English through e-learning, while $48.8 \%$ of students did not understand learning English through e-learning well. This question also relates to the indicator of self-confidence and the researcher did not find any problems in this item.

Question number 4 "Do you feel forced to use E-Learning because it is required by the teacher?". Shows that $87.2 \%$ of students chose "No" it means most of the students do not feel forced when learning English through e-learning. Whereas $12.8 \%$ of students are feel forced to learning English through e-learning. This question relates to the indicator of students attitude.

Question number 5 "Are you motivated to improve your English skills when learning used ELearning?". Shows that $82.6 \%$ of students are motivated to improve their English skills when learning through e-learning. This question belongs to internal factors related to motivational indicators, which encourage themselves to be better.

Question number 6 "Are you interested in learning English using E-Learning?". Shows that $87.2 \%$ of students were interested in learning English through e-learning, while $12.8 \%$ of students were not interested in learning English through e-learning. Similar to the question number 4 , these two questions are related to one and another due to internal factors and indicators of students' attitudes towards e-learning.

On the questionnaire number 7 "Have you been given training on how to use electronics before learning English through E-learning?". Shows that $65,1 \%$ or 56 of 86 students chose "No", it means they still have not experienced training specifically about how to use an audio headset in a language lab, how to operate a computer and the internet. This case referred to the indicator 
of self esteem because the lack of students experience with electronic makes them feel inferior whenever the e-learning applied.

Item questionnaire number 8 "Do you know how to learn English using E-Learning?" $62.8 \%$ of students chose "No" and $37.2 \%$ of students chose "Yes" It can be stated that there are more than half of the students who still do not understand what e-learning is and how the e-learning system works. Similar as the problem that the researcher explained before, these two problem items are related to each other, there are still problems in internal factors contained in the indicators of self-esteem.

Question number 9 "Are you having trouble understanding information in English learning provided through E-learning?" Shows 59.3\% of students did not have significant difficulties in understanding English learning through e-learning and many of the students feel better and understand quickly when the teacher teaches English through e-leaning. Similar to the previous questions number 7 and 8 , these three questions are interrelated because these are involve indicators of self-esteem in internal factors.

Table 3. Problems from External Factor

\begin{tabular}{|c|c|c|c|}
\hline \multirow{2}{*}{ NO } & \multirow{2}{*}{ Item Questionnaire } & \multicolumn{2}{|c|}{ Frequency $(\%)$} \\
\hline & & Yes & No \\
\hline \multirow{2}{*}{10} & \multirow{2}{*}{$\begin{array}{l}\text { Does your school has an adequate number of } \\
\text { computers for all students? }\end{array}$} & $91,9 \%$ & $8,1 \%$ \\
\hline & & $(79)$ & (7) \\
\hline \multirow{2}{*}{11} & \multirow{2}{*}{ Do you often use e-books to learn English? } & $16,3 \%$ & $83,7 \%$ \\
\hline & & $(14)$ & $(72)$ \\
\hline \multirow{2}{*}{12} & \multirow{2}{*}{$\begin{array}{l}\text { Do you hear audio listening well in English } \\
\text { lessons through e-learning? }\end{array}$} & $52,3 \%$ & $47,7 \%$ \\
\hline & & $(45)$ & $(41)$ \\
\hline \multirow{2}{*}{13} & \multirow{2}{*}{$\begin{array}{l}\text { Is the internet connection goes down while } \\
\text { learning English through e-learning? }\end{array}$} & $15,1 \%$ & $84,9 \%$ \\
\hline & & (13) & (73) \\
\hline \multirow[b]{2}{*}{14} & \multirow{2}{*}{$\begin{array}{l}\text { Is the electronic device having trouble while } \\
\text { it's used? example: LCD projector, computer, } \\
\text { tape recorder. }\end{array}$} & $25,6 \%$ & $74,4 \%$ \\
\hline & & $(22)$ & $(64)$ \\
\hline \multirow{2}{*}{15} & \multirow{2}{*}{$\begin{array}{l}\text { whether the time provided by the school to } \\
\text { learn English through E-Learning enough? }\end{array}$} & $73,3 \%$ & $26,7 \%$ \\
\hline & & $(63)$ & $(23)$ \\
\hline \multirow{2}{*}{16} & \multirow{2}{*}{$\begin{array}{l}\text { Does the preparation for using electronics take } \\
\text { a lot of time, so that the time is wasted? }\end{array}$} & $12,8 \%$ & $87,2 \%$ \\
\hline & & $(11)$ & $(75)$ \\
\hline 17 & $\begin{array}{l}\text { Is the way of teachers teach are fun when } \\
\text { teaching English through E-learning? }\end{array}$ & $\begin{array}{c}76,7 \% \\
(66)\end{array}$ & $\begin{array}{c}23,3 \% \\
(20)\end{array}$ \\
\hline \multirow[b]{2}{*}{18} & \multirow{2}{*}{$\begin{array}{l}\text { Do you want to learning English through E- } \\
\text { Learning but the teacher doesn't use it? }\end{array}$} & $54,7 \%$ & $45,3 \%$ \\
\hline & & $(47)$ & (39) \\
\hline
\end{tabular}

The results show that external factor has several problems, which is found in number 11 and number 18. At this point, the researcher will describes all of the items contained in external factor, as follows:

Question number 10 "Does your school has an adequate number of computers for all students?" shows that $91.9 \%$ of students agreed that their school had enough computers for all of the students. This question item is from the external factor contained in the indicator of teaching media, but in this case the researcher did not found any significant problems.

Item Questionnaire number 11 "Do you often use e-books to learn English?" 83.7\% of students chose "No" it means there are 72 students who still lack the use of the internet for learning and the school does not provide e-books for students. Whereas, there are 16,3\% students already use e-books for learning English both at home and at school. External factors that obstruct 
students from learning English through e-learning for example: teaching media which are still not applied by teacher even the school has provided all the infrastructure.

Question number 12 "Do you hear audio listening well in English lessons through e-learning?" This question showed that $52.3 \%$ of students agreed that they heard audio listening well without any significant interference problems. While $47.7 \%$ of students did not hear audio listening well and there are many factors caused the students unable to hear audio listening well. On the other hand, this case is not a serious problem because the majority of the students are able to hear audio listening well. This question is also related to external factors, especially in the indicators of teaching media.

Question number 13 "Is the internet connection going down while learning English through elearning?" This question showed that $84.9 \%$ of students chose "No" which means that they have no problems with internet connections provided by the school. Therefore, this question is not a problem because the majority agreed that there is no problem with internet connection. This question also related with external factors in teaching media indicators.

Question number 14 "Is the electronic device having trouble while it's used? Example: LCD projector, computer, tape recorder." It shows that $74.4 \%$ of students choose "No" which means that they have no problems with the electronic devices that they used. This question is still related to external factors of teaching media indicators, and no significant problems were found in this question.

Question number 15 " Whether the time provided by the school to learn English through ELearning enough?" It shows that $73.3 \%$ of students agreed that they had sufficient time in learning English through e-learning. This question is related to external factors in indicators of classroom condition, and no significant problems were found by the researcher.

Question number 16 "Does the preparation for using electronics take a lot of time, so that time is wasted?" It shows that $87.2 \%$ of students do not feel that the time spent on preparation used a lot of time means time is wasted. This question is similar as the previous question above that focused on the readiness of the teacher in time management. This question also deals with external factors in the class condition indicators, and no significant problems were found by the researcher.

Question number 17 "Is the way the teacher teaches are fun when teaching English through Elearning?" It shows that $76.7 \%$ of students agreed that the way teacher teach was more fun when learning English through e-learning than conventional learning methods. The teacher's experience in teaching using e-learning can also support the creativity of teachers in teaching. In this case, no significant problems were found by the researcher.

Question number 18 "Do you want to learn through E-Learning but the teacher does not use it?" $54,7 \%$ or 47 of 86 students chose "Yes". The researcher has found that teachers still infrequently use e-learning in the classroom or introduce e-learning to students. Therefore, this problem is also included in external factors, more precisely to the teacher's attitude.

Question number 19 "Does the teacher provide guidance on how to use electronics in learning English through E-Learning?" It shows that 53.5\% of students agreed that the teacher gave direction on how to use electronic devices. While $46.5 \%$ of students dissagree that the teacher gave direction on how to use electronic devices. This question is related to external factors in 
indicators of teacher experience similar to the question number 17. The teacher experience in teaching using e-learning can also support success in the classroom. In this case, no significant problems were discovered by the researcher.

\section{Discussion}

In accordance with the research objective as explained in chapter 1 that is to find out what problems encountered by students when learning English through E-Learning. In this session, the researcher explains about the discussion of the results that have been obtained and compared with the results obtained from previous research.

There are many indicator in the questionnaire but the researcher found that the indicator of selfesteem as internal factor and the indicator of teacher attitude and teaching media as external factor are the students problems in learning English through e-learning in SMP Katolik 1 WR Soepratman. On the indicator of self-esteem, the researcher found that the students did not get instructions from the teacher regarding the use of electronic devices for learning purposes and in the end this makes students did not know enough what e learning is. Meanwhile, teaching media and teachers attitude is the problem for students because the questionnaire shows that there is a high percentage of problems on these indicators.

As previously explained that self-esteem is a problem for students in SMP Katolik 1 WR Soepratman. Furthermore, researcher found that the students have little experience in using electronic devices as an educational purpose. However, researcher found the fact that the students are proficient in using computers as well internet but beyond educational needs. This condition is exacerbated by the lack of emphasis from the school in the use of e-learning for learning English. In the end, the students feel insecure at the time the teacher teaches English through e-learning. In this condition, researcher agree with what was said by Mohammed (2015) that students still need more training in the use of electronics in learning English through e-learning. In the same line, researcher also found that most students were not accustomed to matters relating to electronics for educational purposes, similar to Mohammed (2015) research where the subjects also still needed training to use technology.

Next fact, the researcher found that the majority of the students do not understand about what is e-learning. This case also relates to self-esteem indicators contained in students' internal factors, where the students feels inferior when they do not have enough knowledge about elearning, Compared [7] they found only a few students who still did not understand about elearning. It was not a problem for them because the subjects were mostly familiar with elearning and had a lot of information about it.

The researcher found the problem with a high percentage that students are still lacking in using e-books or online journals to study. They still often use the conventional way by using printed books provided by schools or purchased by students. This problem is related to the indicator of teaching media that is contained in external factors. Lack of emphasis from the school to use ebooks, even more likely to provide printed books in learning process can be the reason why students use e-book very rarely when learning English through e-learning. A similar problem was also found by [9], not many students use online journals or e-books for learning. From these two findings, the researcher concluded that there were still many students were not familiar with online books or journals for learning.

The last but not least, the researcher also found that the teachers have a low attitude response towards e-learning, which is found on external factors. The researcher found that many students 
want to learn English through e-learning but teachers still rarely teach using e-learning. Many factors influence the lack of use of e-learning to teach, that are teacher's lack of understanding of the importance of e learning and lack of knowledge of using technology. This happens because they are in a generation where technological advances are minimal which makes teachers are difficult to keep abreast of technological developments that exist today. Furthermore, the lack of teacher training and lack of school contributions to require teachers to use technology in classroom is the reason as well. However, different result with Haron \& Zaid (2015) whereby they found that students are often taught using technology and they get quite a lot of information about e-learning, therefore they have no problems about this case.

\section{Conclusion}

From the findings that have been obtained, the researcher concludes that the problems faced by students of SMP Katolik 1 WR Soepratman Samarinda when learning English through elearning are from the indicator of self-esteem as internal factor and the indicator of teacher attitude and teaching media as external factor. Furthermore, the problem from internal and external factor are listed as bellow:

a. Lack of training given to students about E-learning (problem from internal factor, related to the indicator of self-esteem).

b. Lack of knowledge about e-learning (problem from internal factor, related to the indicator of self-esteem).

c. Lack of using e-books (problem from external factor, related to the indicator of teaching media).

d. Teachers who still infrequently use e-learning when teaching English (problem from external factor, related to the indicator of teacher attitude)

Problems that the researcher found, both in terms of internal and external factor, each part are interrelated. Problem that happened with the teachers, then to the students and eventually impact the learning system which makes ineffectiveness e-learning in the school, they are affecting each other and create a domino effect. This phenomenon concluded by trace the cause of the problems, which can be started by recognize that most of the students are proficient in using computers as well internet but beyond educational needs. This condition is exacerbated by the lack of emphasis from the school toward the teachers to apply e-learning. After that, there are still limited access in the school for learning through e-learning, in hence students are still not introduced about what e-learning is and they do not know how to learn English through e-learning due to lack of information. Next, SMP Katolik 1 WR Soepratman Samarinda still applied the conventional way by using printed books provided by schools or purchased by students as the teaching material. The last but not least, the teacher's problem are caused because they are live in a generation where technological advances are minimal which makes teachers are difficult to keep abreast of technological developments that exist today. Besides that, the lack of teacher training and lack of school contributions to require teachers to use technology in classroom is the reason as well.

\section{References}

[1] M. Aparicio, F. Bacao, and T. Oliveira, T, "An e-Learning Theoretical Framework", Educational Technology \& Society, 2016.

[2] J. Bacon-shone, "Introduction to Quantitative Research Methods", Hong Kong: Graduate School, 2015.

[3] D. Cramer, and D. Howitt, "Introduction to Statistics in Psychology", Boston: Pearson Education, 2011.

[4] P. Gaur, (2016), "Research Trends in E-Learning", Media Communique, 2016.

[5] L.R. Gay, "Educational Research Competencies for Analysis and Applications", Boston: 
BORJU:Borneo Educational Journal

ISSN 2655-9323 (online)

Pearson Education, 2012.

[6] A.P. Gilakjani, N.B. Sabouri, and A. Zabihniaemran, "What Are the Barriers in the Use of Computer Technology in EFL Instruction?", Canadian Center of Science and Education, 7(11), 213-221, 2015.

[7] N.N. Haron, and Y.H. Zaid, "E-Learning as a Platform to Learn English among ESL Learners : Benefits and Barriers", UTM Press, 2015.

[8] V.P. Hasibuan, S. Buan, and E. Bunau, "An Analysis on the Factors Causing English", 015, 2013.

[9] M.I. Mohammed, "The Perceptions of Students and Teachers about The Benefits of And Barriers to Technology aided EFL", Journal of Literature, Languages and Linguistics, 13(2010), 85-100, 2015.

[10] M.M. Trasierra, "The Use of Technology in EFL Classroms: Advantages and Disadvantages", Final Degree Project, 2018.

[11] P. Westwood, "What teachers need to know about Reading and writing difficulties", Camberwell Victoria, Australia: ACER Press, 2008. 